\title{
INVESTIGATING THE IMPLEMENTATION OF GOOGLE CLASSROOM TO IMPROVE READING COMPREHENSION: ADVANTAGE AND DISADVANTAGE
}

\author{
${ }^{1}$ Lusi Susanti, ${ }^{2}$ Esti Junining, \& ${ }^{2}$ Hamamah \\ ${ }^{1}$ Student, Linguistic Study Program, Brawijaya University, Indonesia. \\ ${ }^{2}$ Lecturer, Linguistic Study Program, Brawijaya University, Indonesia. \\ Corresponding Author Email: lusisusanti01@student.ub.ac.id
}

\begin{tabular}{ll}
\hline \hline Article Info & Abstract \\
\hline Article History & When deciding to use the media, of course, the decision to use the media must be \\
Received: February 2021 & able to accept the advantages and disadvantages of the media. The advantages of \\
Revised: April 2021 & media users are expected to increase understanding in using the media. On the \\
Published: April 2021 & other hand, the disadvantages when using media are expected to be minimized \\
\hline Keywords & This study investigates the advantages and disadvantages and the effectiveness of \\
Google classroom; & using Google classroom media to improve students' reading comprehension. The \\
Reading Comprehension; & method used is a descriptive qualitative study. This study indicates that the use of \\
& Google Classroom media is effective in the learning process in ELT settings. This \\
& research presents the benefits of using this media in the learning process to \\
& improve reading comprehension. It can be accessed anytime and anywhere, \\
& flexible time, and a more innovative learning model (based on E-learning). Some \\
of the benefits that can be obtained from using Google media, some shortcomings \\
are encountered when using this media. Students must have a Google account; \\
there is no face-to-face class; must be connected to the internet; and waste of \\
internet financing.
\end{tabular}

How to cite: Susanti, L., Juninang, E., \& Hamamah. (2021). Investigating the implementation of google classroom to improve reading comprehension: Advantage and disadvantage, JOLLT Journal of Languages and Language Teaching, 9(2), 204-211, DOI: https://doi.org/10.33394/jollt.v\%vi\%i.3491

\section{INTRODUCTION}

Technological development continues to grow along with the progress of the times continue to globalize. It has an impact on various aspects, including the world of education. The number of applications offered to facilitate the learning process is also a result of the impact of technological advances that impact education. E-Learning is one of the concepts of the Learning Management System (LMS). It is designed to define specifications for the process, instruction, or instructional resources, evaluate and disclose data obtained automatically using electronic means. For instance, computers or electronic devices such as software or other electronic media are used for different purposes (Ferdianto \& Dwiniasih, 2019). LMS (Learning Management system) is the most widely used software in educational technology, one of which is Google Classroom, for example, Moodle, Blackboard, Edmodo, Schoology, Google Classroom, etc.

Easy internet access also provides extensive opportunities for online-based education. According to Inoue and Pengnate in Alim (2019), Google Classroom also helps to reduce costs incurred due to the use of more inexpensive stationery and other raw material and can minimize time-consuming energy. In addition, Hammi, in Nirfayanti (2019), argues that Google Classroom is a technology that allows cyberspace classrooms to be developed. Google Classroom can also be used to allocate assignments, request evaluations, and even review submitted assignments. Google Classroom itself can be interpreted as an online-based class. Google Classroom is a new tool that was introduced in Google Apps for Education in 
2014. Some of the advantages of using Google class media include being accessible anytime and anywhere, flexible time, more innovative learning models (based on E-learning).

Google Classroom as a medium can be used in the learning process. This class allows teachers to quickly develop and organize work, provide feedback effectively and communicate easily with their class. According to Donald Yates (2017) in Sukmawati (2019), Google Classroom is to provide an integrated learning environment in schools to facilitate the development of paperwork and marking for students. Google classroom media offered is expected to improve the level of education better. In this case, Google Classroom is applied in learning to read comprehension. The importance of reading learning is also contained in the 1945 Constitution that emphasizes the importance of reading and writing proficiency and proficiency, proficiency arithmetic, and communication skills " Khasanah, (2016). It is clear that reading is one of the keys to achieving other abilities such as writing, counting to communicate. In addition, Strevens in Verdiansyah (2020) argues that the ability to read is a crucial tool between both the teacher and the learner because reading gives access to a broad range of language skills and knowledge. Next, Ruslan (2019) says that reading activities are very important for everyone to increase their knowledge.

On the other hand, according to the Dean in Muslaini (2017), reading is more than simply seeing sentences, more than spelling out written words properly, and more than understanding the significance of individual words. Reading is not only looking at words in the book and pronouncing them, but knowing all the elements of a book. Talking about knowing the element of reading, it's not separated from reading comprehension. it's in accordance with Cain's statement in Ahmadi (2017), which argues that Reading comprehension is classified by incorporating a range of processes involving language, reading ability, word knowledge, and fluency as the process of making meaning. This is consistent with the theory of Mickulecky \& Jeffries in Ismail (2017) that reading is very important because it can develop the general language skills of students in English; helping students think in English, expanding the English vocabulary of students, improving their writing, and it can be a good way to get new insights, information, and experiences. Also, McMaster, Espin, \& Van den Broek in Setyadi et al. (2019) asserted that reading comprehension is a method of consciously gaining meaning through the involvement of readers with information and expertise relevant to the quality of reading.

In several previous studies, the involvement of Google Classroom emphasized the effectiveness of Google Classroom, Perceptions of the use of Google Classroom, Google Classroom as a learning medium in a university, Google Classroom as a supporter of the Teaching and Learning Process in this study. The author wants to convey the role of Google Classroom as a medium to improve reading skills ability. According to Hakim (2016) in Sabran (2019), the Google Classroom application aims to simplify the learning process and help teachers manage classes. Some features contained in the Google Classroom media can be utilized by teachers to further facilitate learning activities in the Google Classroom media. Next, Hamiyah and Jauhar (2014) in Pradana (2017) say the learning model is a design prepared through visual media to help visualize the message contained in it to achieve the objectives of the learning process.

The importance of good reading skills greatly affects students' understanding of reading activities. Besides being able to obtain a lot of useful information and insights, reading can also foster students' creativity. This study aims to determine the advantages and disadvantages as well as the effectiveness of using Google classroom media in the learning process. 


\section{RESEARCH METHOD \\ Research Design}

This research uses the descriptive qualitative method. According to Cresswel (2014), qualitative research is one of the research techniques that provide concise evidence in the form of speech or writing, and a person's action that is analyzed in a specific context that is studied from a systematic, comprehensive, and integrated viewpoint.

\section{Population and sample}

This research was conducted at the PDD campus of the Pontianak State Polytechnic in Putussibau, West Kalimantan. The population in this study was the first semester students of Aquaculture Technology (TBP). The reason for taking this population is that students cannot be separated from the learning process. The presence of Google Classroom certainly has a significant influence both on the advantages of using Google Classroom and the disadvantages of using Google Classroom. With this population, it is hoped that Google Classroom can effectively use some of its features in the learning process. The total number of samples in the study consisted of two classes, namely TBP A and TBP B, totaling 30 students

\section{Instruments}

The instruments of this study employ observation, questionnaires, and documentation. Observations were made to observe student activities to obtain data related to the object of research. In this study, the observation used as participant observation in which the researcher was directly involved with the object under study. Further data collection was carried out through questionnaires. The questionnaire used is a closed questionnaire, where students can directly choose the answers that have been provided. The questionnaire items of this study can be presented in Table 1 as follows.

Table 1

Research Questionnaire of the Use of Google Classroom

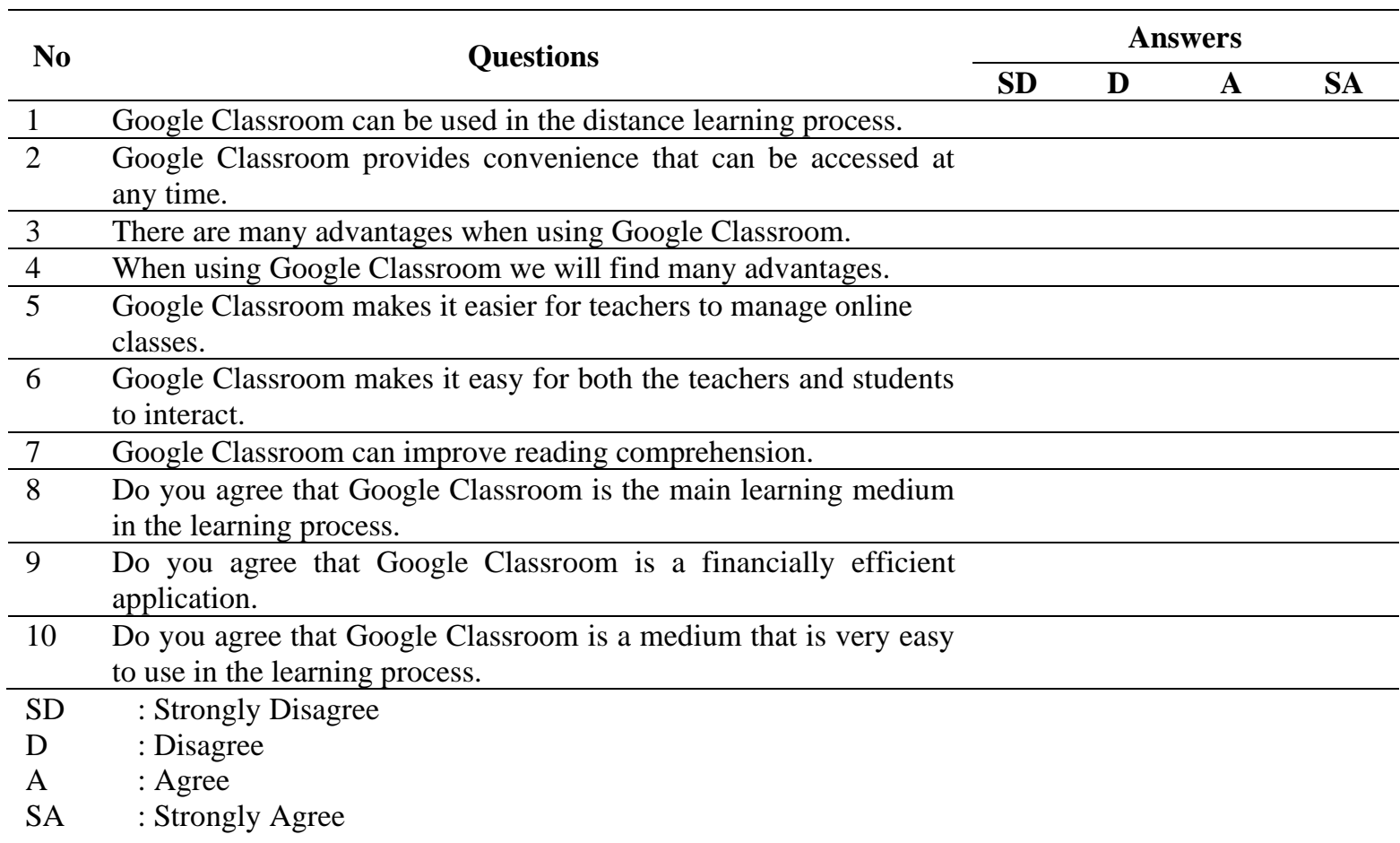

The latest data collected from the documentation. This research documentation in the form of lesson plans, textbooks, worksheets, and student attendance. The documentation aims to confirm that the implementation of the google classroom happens in the school. 


\section{Data Analysis}

The data analysis in this study was carried out in several steps. The first step is observation. This observation was carried out on TBP students as research objects. This is done to obtain accurate information. In addition to student involvement as the object under study, the direct involvement of researchers also plays a very important role in the observation of this research because this observation is participant observation. So that researchers can directly observe every activity using the sense of sight or hearing. In line with that, Guba and Lincoln in Hamzah (2019) said that observation is an activity related to the senses so that they can obtain the information needed to be able to answer problems in research. In this study, the researcher involved himself in every activity and noted important things that happened in the field regarding research. The second step in this research is a questionnaire. In addition to making observations, researchers also conducted surveys by giving questionnaires to students about the advantages and disadvantages of Google Classroom. Furthermore is the documentation analysis. The documentation analysis in this research was carried out by presenting the documentation data obtained in the field into a narrative test in the form of field.

\section{RESEARCH FINDINGS AND DISCUSSION Research Findings}

This section contains the results of research and analysis done with an emphasis on the answer to the problems. The author(s) is recommended to discuss the results according to the findings. In research findings, the author(s) is expected to report the results of procedures in the previous section and to display the data (text, tables, and/or figures) that supports further discussion. Any kind of data should be displayed chronologically, as mentioned in the section about methods. The percentage of the use of google classroom can be seen in Table 2 as follows.

Table 2

Recapitulation of Aquaculture Technology (TBP) survey

\begin{tabular}{clccc}
\hline No & & Alternatif & Jumlah & Persentase $\%$ \\
\hline 1 & Strongly Agree & 4 & 13.33 \\
\hline 2 & Agree & 24 & 80,00 \\
\hline 3 & Disagree & 2 & 6,67 \\
\hline 4 & Strongly disagree & 0 & 0 \\
\hline
\end{tabular}

The recapitulation of the TBP student survey shows the results that Google Classroom can be used in the learning process. The many advantages of using Google Classroom can minimize the shortcomings when using Google Classroom. This is evidenced by the results that state that TBP students agree that the Google Classroom application provides a lot of convenience in the learning process. The acquisition of $80.00 \%$ strongly agrees $13.33 \%$, disagrees as much as $6.67 \%$, and for the category strongly disagrees $0 \%$.

\section{The advantages of Google Classroom media to increase reading comprehension}

One of the benefits of Google classroom media is the convenience that can be accessed anytime and anywhere. It can be accessed anytime and anywhere. This makes it easier to use Google classroom learning media. In addition to easy access to learning, it also makes it easier for students to find references related to the material being discussed. Also, Google classroom media is an online-based class; flexible time provides convenience for students and teachers. So the learning process can be carried out by the agreed agreement. Because it is done in a paperless way, the learning process using this media saves time both for teachers and students. In addition, students can also complete assignments more on time. 
Many facilities offered in the Google Classroom media facilitate students in using the learning management system. One of them is the availability of the "classwork" menu. This menu will group files into two, namely task files and material files. Google Classroom allows for more purposeful and effective teaching and learning activities by simplifying worksheets, increasing collaboration, and fostering communication. Teachers can build courses, give tasks, provide reviews and see everything in one place. Some of the advantages contained in the findings in this study are also supported by the results of previous research conducted by Laili and Muflihah in 2020, which stated that Google Classroom was very effective and efficient and had a significant effect on student writing performance. In addition, Soni et al. (2018) say that learning activities through Google Classroom are more effective because both teachers and students can have conversations through applications offered by Google.

\section{The disadvantages of Google Classroom media to increase reading comprehension}

One of the requirements to be able to use Google Classroom learning media is that every participant or student must have a Google account by registering with a Google account. To get the Google facility for free, first, register a Google account which can be done for free. Various facilities are offered, one of which is the Google classroom. Google classroom is an online-based classroom. There are no face-to-face classes, all done through elearning. This is certainly not as optimal as when learning is done by interacting directly. Many shortcomings when choosing not to use classrooms, as usual, one of which is the absence of direct interaction between students and teachers. Of course, this can also have an effect on students' emotions. If students normally learn from collaboration and togetherness by using the learning process with this E-learning system, the students' character is unconsciously directed at individualism.

This is the most important thing when choosing to use a Google media classroom, an internet-based class. The location and situation of the signal certainly greatly affect the connection to the internet network. Therefore, learning with Google classroom media cannot be used when no internet service supports it. Therefore this media may not be used in certain areas that do not have stable networks. In addition, internet service has become an obstacle, and internet costs are also a consideration in using online-based learning media, in this case, especially Google classroom media. This cannot be avoided if we choose to use media that is connected to the internet network, so we must be prepared with a cost that is not insignificant compared to the offline learning process.

\section{Discussion}

The role of Google Classroom media to increase reading comprehension

The flexible time provided by Google Classroom makes it easier to access anytime and anywhere. The innovative learning offered provides a special attraction for students who use Google Classroom as a substitute class for face-to-face classes into synchronous and asynchronous classes. Google Classroom can send files and images and videos that support learning can be sent through this application. By Google Drive, all assignments, Google Docs, Sheets, and slides can be easily accessed. Thus, the convenience offered by Google Classroom, consciously or not, can increase students' understanding and reading proficiency because every step provided by Google classroom requires students to be more careful so that they can go to the next step to reduce virtual classrooms. 


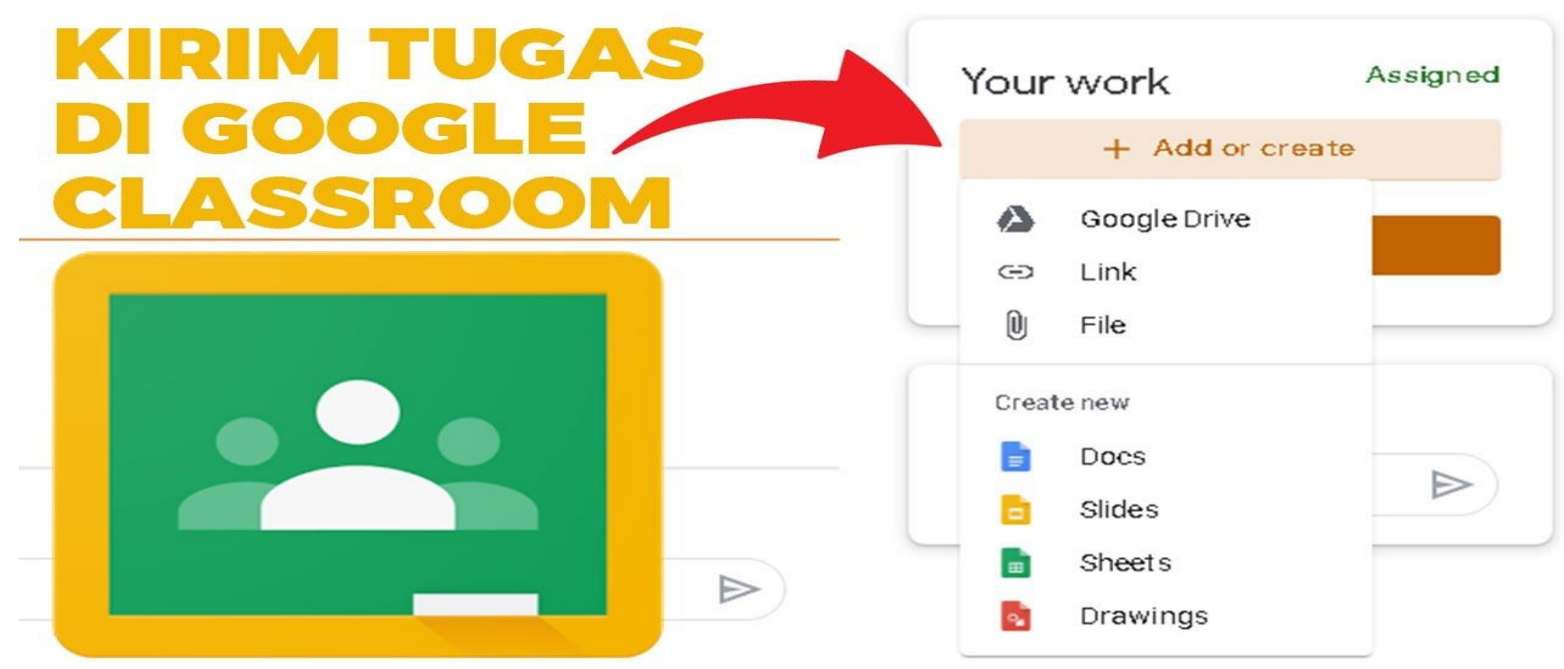

Figure 1. how to submit assignments in Google Classroom

Each student must send an assignment, whether it is a quiz assignment, multiple-choice, or a question that has been given through Google Classroom. Through the image instructions above, teachers can follow the steps in submitting an assignment. Besides having a forum room for discussion, Google Classroom also provides a comment column that can be used to ask questions or provide comments in private.

\section{The effectiveness of Google Classroom media to increase reading comprehension}

The setting process is comfortable and allows making the learning process more effective, and students only need to have a Google account to be able to connect and take classes virtually. With Google Classroom, it can save time, and the convenience offered by Google Classroom is very helpful for both educators and students. Whether they realize it or not, students will be more careful in using the Google Classroom application or in doing assignments because they are required to reduce the existing steps both in using Google Classroom in the learning process so that they will read every available section. Students can also provide feedback comments directly, as in face-to-face class. Google Classroom also offers convenience in the form of secure data storage. Students or teachers can directly see the assignments and grades that have been given in this application.

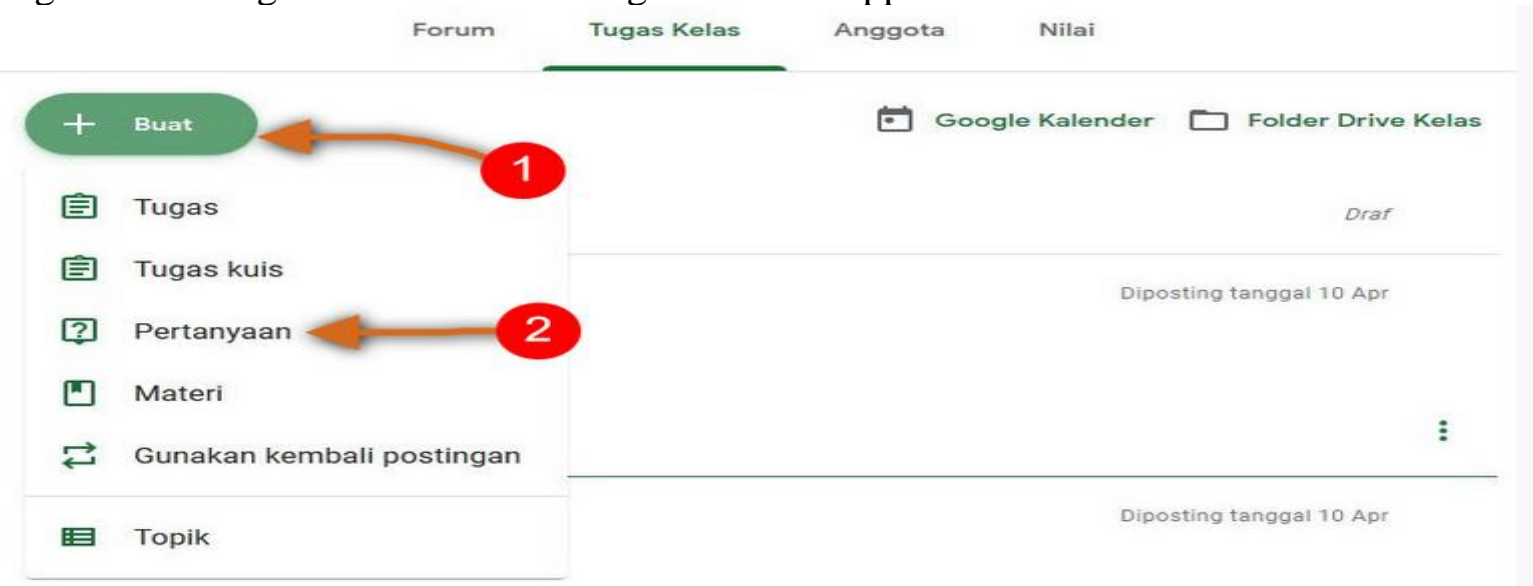

Figure 2. how to make an assignment

The picture above shows how to create assignments in Google Classroom. This application also provides a choice of the form of the assignment that we will use, for example 
assignments in the form of material, quizzes (multiple choice), or assignments in the form of essay questions.

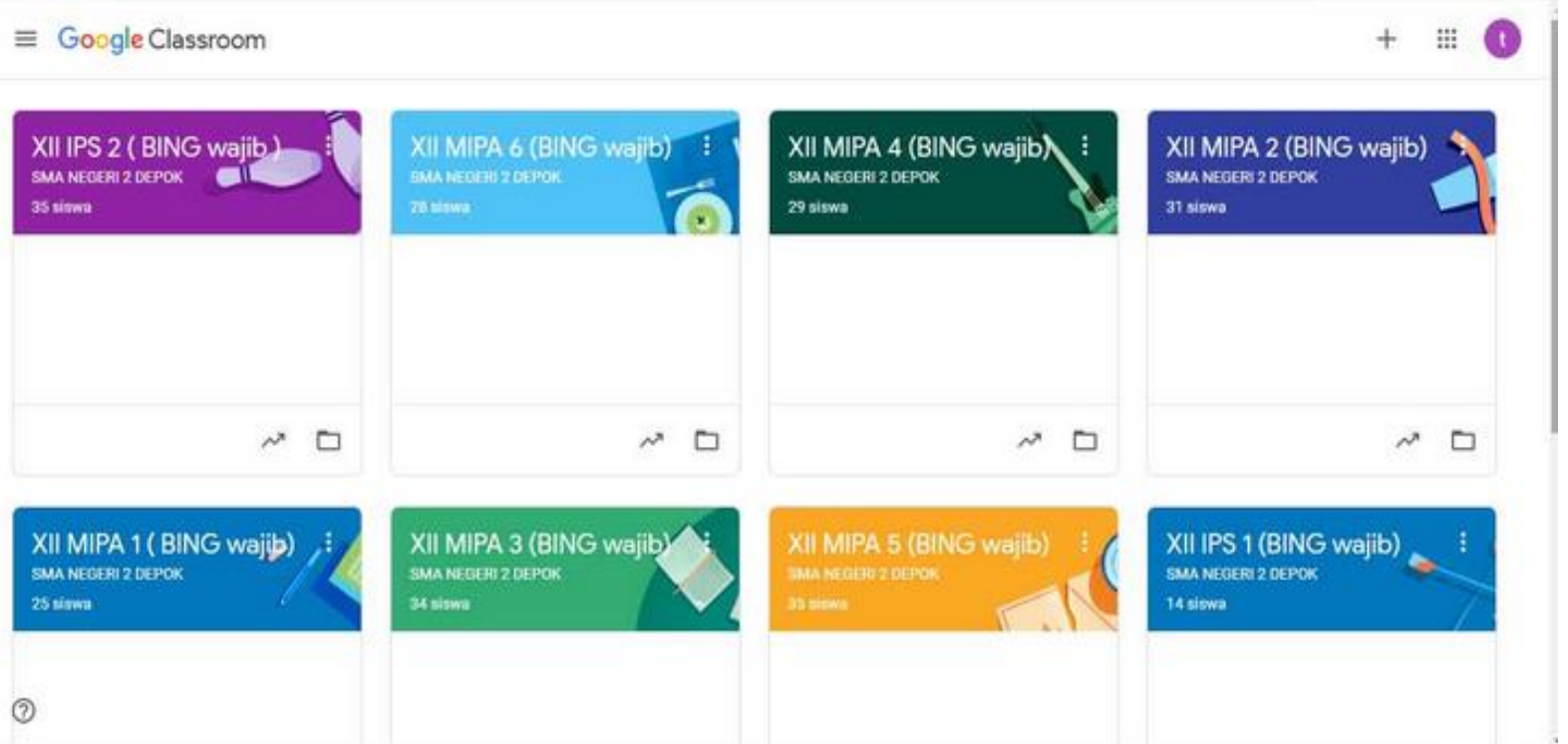

Figure 3. how to create a few class in one Google Classroom media

The picture above shows one of the Google Classroom features that can help the learning process become easier. With one Google Classroom application, the teacher can create several classes of subjects. This is very helpful and saves space and time in class management.

\section{CONCLUSION}

The latest features offered by Google classroom greatly assist students in doing assignments with flexible access time. As well as innovative learning can help students be more creative. From some of the conveniences offered by the Google classroom media, several things must be considered when using this learning media. The ease of access offered must be by the circumstances. Every student who follows e-learning in the form of Google classroom must have an account first. Besides that, when there are problems regarding the material presented, students can only ask questions through Google classroom, and the teacher also responds through Google classroom, so when there are obstacles encountered by students and they cannot get a response directly because there are no face-to-face classes. This is certainly different from the presence of classes directly. Finally, in addition to the aforementioned obstacles, internet costs are also one of the inhibiting factors in joining Google classroom. The use of Google Classroom provides quite a convenience with the features offered. From this explanation, this study can be concluded that the Google classroom media is not the only perfect media, but the Google classroom media can provide fresh air for easier and wider access, considering that this media is netted on the internet.

\section{ACKNOWLEDGEMENT}

The author would like to thank all of the parties involved in completing this research. Furthermore, thanks are also conveyed to the Pontianak State Polytechnic PDD campus, especially the Aquaculture Technology Study Program, which has provided the opportunity and support to carry out this research. Finally, the author also thanks the Journal of Languages and Language Teaching Journal (JOLLT) for the chance to publish this article. 


\section{REFERENCES}

Ahmadi, M. R. (2017). The impact of motivation on reading comprehension. International Journal of Research in English Education, 2(1), 1-7.

Alim, N., Linda, W., Gunawan, F., \& Saad, M. S. M. (2019). The effectiveness of Google classroom as an instructional media: A case of state islamic institute of Kendari, Indonesia. Humanities \& Social Sciences Reviews, 7(2), 240-246.

Ferdianto, F. (2019, October). Learning Management System (LMS) schoology: Why it's important and what it looks like. In Journal of Physics: Conference Series (Vol. 1360, No. 1, p. 012034). IOP Publishing.

Hamzah, Amir. (2019). Metode Penelitian Kualitatif. Malang. Literasi Nusantara.

Ismail, H., Syahruzah, J. K., \& Basuki, B. (2017). Improving the students' reading skill through translation method. Journal of English Education, 2(2), 124-131.

Khasanah, A., \& Cahyani, I. (2016). Peningkatan kemampuan membaca pemahaman dengan Strategi question answer relationships (qar) Pada Siswa Kelas V Sekolah Dasar. Pedagogik Pendidikan Dasar, 1(2).

Laili, E. N., \& Muflihah, T. (2020). The Effectiveness of Google Classroom In Teaching Writing of Recount Text For Senior High Schools. Journal of Languages and Language Teaching, 8(4), 348-359.

Muslaini, M. (2017). Strategies for teaching reading comprehension. English Education Journal, 8(1), 66-77.

Nirfayanti, N., \& Nurbaeti, N. (2019). Pengaruh Media Pembelajaran Google Classroom Dalam Pembelajaran Analisis Real Terhadap Motivasi Belajar Mahasiswa. Proximal: Jurnal Penelitian Matematika dan Pendidikan Matematika, 2(1), 50-59.

Pradana, D. B. P. (2017). Pengaruh penerapan tools google classroom pada model pembelajaran project based learning terhadap hasil belajar siswa. IT-Edu: Jurnal Information Technology and Education, 2(01).

Ruslan, R., \& Wibayanti, S. H. (2019, March). Pentingnya Meningkatkan Minat Baca Siswa. In prosiding seminar nasional program pascasarjana universitas pgri palembang (Vol. 12, No. 01).

Sabran, S., \& Sabara, E. (2019, February). Keefektifan Google Classroom sebagai media pembelajaran. In Seminar Nasional LP2M UNM.

Setiyadi, R., Kuswendi, U., \& Ristiana, M. G. (2019, August). Learning of Reading Comprehension through Reading Workshop in the Industry 4.0. In Elementary School Forum (Mimbar Sekolah Dasar) (Vol. 6, No. 2, pp. 160-173). Indonesia University of Education. J1. Mayor Abdurachman No. 211, Sumedang, Jawa Barat, 45322, Indonesia. Web site: https://ejournal. upi. edu/index. php/mimbar/index.

Soni, S., Hafid, A., Hayami, R., Fatma, Y., Wenando, F. A., Al Amien, J., ... \& Hasanuddin, H. (2018). Optimalisasi penggunaan google classroom, e-learning \& blended learning sebagai media pembelajaran bagi guru dan siswa di smk negeri 1 bangkinang. Jurnal Pengabdian UntukMu NegeRI, 2(1), 17-20.

Sukmawati, S., \& Nensia, N. (2019). The Role of Google Classroom in ELT. International Journal for Educational and Vocational Studies, 1(2), 142-145.

Verdiansyah, M. Z., Sahiruddin, S., \& Degeng, P. D. D. (2020). Text Complexity in Reading Texts of Indonesian Senior High School English Textbooks Using Coh-Metrix 3.0. Diglossia: Jurnal Kajian Ilmiah Kebahasaan dan Kesusastraan, 12(1), 1-10. 